\title{
THE EFFECT OF KNOWLEDGE SOURCES ON INNOVATION CAPABILITIES AMONG RESTAURANTS AND CAFÉ BUSINESSES IN INDONESIA
}

\author{
Tri Lestari Wahyuning Utami \\ Faculty of Economics and Business, Universitas Gadjah Mada, Indonesia \\ (trilestari.wahyu@mail.ugm.ac.id) \\ Nurul Indarti \\ Faculty of Economics and Business, Universitas Gadjah Mada, Indonesia \\ (nurulindarti@ugm.ac.id) \\ Sari Sitalaksmi \\ Faculty of Economics and Business, Universitas Gadjah Mada, Indonesia \\ (sarisitalaksmi@ugm.ac.id) \\ Nuraksa Makodian \\ Faculty of Economics and Business, Universitas Gadjah Mada, Indonesia \\ (nuraksa.makodian@ugm.ac.id)
}

\begin{abstract}
To conduct innovation, firms absorb and utilise internal and external knowledge. This study examines the effect of internal and external knowledge, in terms of the breadth and depth of knowledge sources, on a firm's innovation. The breadth of knowledge sources refers to the amount of knowledge sources used within the firm. The depth of knowledge sources is the amount of knowledge sources intensively used by the firm. This study is aimed at answering the following questions. a) What knowledge sources are mainly used? b) What type of innovation is frequently conducted? c) What are the effects of the breadth and the depth of knowledge sources on the innovation capabilities among Indonesian restaurants and cafés? The resource-based view and resource dependency theory are used to understand the role of internal and external knowledge on innovation within a firm.

We distributed a semi-structured questionnaire to 101 owners/managers, using a purposive, in several cities in Indonesia, such as Bandung, Denpasar Bogor, Malang, Yogyakarta and other cities in East Java. The results show that the Indonesian restaurants and cafés utilised external knowledge sources more often than internal ones. The firms produce more incremental product innovations than radical ones. The depth of the internal knowledge sources has a positive significant impact on the firms' innovation capabilities, which supports the previous studies. Meanwhile, the breadth of the internal knowledge sources is found not to have a significant effect on innovation. Additionally, the effects of the breadth and depth of the external knowledge sources on the innovation capabilities are also insignificant.
\end{abstract}

Keywords: breadth and depth of knowledge sources, internal knowledge sources, external knowledge sources, innovation, restaurants and cafés

\section{INTRODUCTION}

Competition forces firms to develop and build their innovation capabilities (Zander and Kogut, 1995; Elche-Hotelano, 2011). To conduct innovation, firms have to generate innovative ideas as the point of departure in the process of innovation (Hansen and Birkinshaw, 2007).
Ideas are created from knowledge that can be obtained from the internal and external sources of the firms (Van den Ende et al., 2014). From the resource-based view of a firm, internal resources (e.g. knowledge) are the important things for sustainable competitive advantage (Barney, 1991). This argument is followed by 
the emerging knowledge-based view that emphasises knowledge as a main source of competitive advantage (see Grant, 1996). Internal knowledge can be obtained through R\&D activities (Frenz and Letto-Gillies, 2009), knowledge sharing (Liao et al., 2007), and collecting ideas from the employees via suggestion systems (Van Djik and Van den Ende, 2002; Verworn, 2009). The internal actors include the employees (see Amara and Landry, 2005; Salge et al., 2013) and the owner of the firm (Indarti, 2010).

Internal knowledge is obtained from the employees (Elche-Hotelano, 2011) and the owner (Indarti, 2010), who are the sources of internal knowledge. Firms leverage new ideas from their employees to transfer ideas into innovations (Van Djik and Van den Ende, 2002). Meanwhile, the owner also supports this by giving knowledge related to his/her role as the decision maker of the innovation (Indarti, 2010). This knowledge from the employees and owner is used to develop innovations, indicated by the variety of the sources of knowledge (Amara and Landry, 2005). Borrowing the concept of the breadth of knowledge sources (Laursen and Salter, 2006), we define the variety of knowledge sources as the breadth of internal knowledge sources. Amara and Landry (2005:254) stated ' ... firms using a larger variety of internal sources of information to develop innovations are more likely to develop innovations that can be considered as world premieres...' That means that the breadth of internal knowledge sources has a positive effect on innovation capabilities.

Employees who take the initiative to think of new ideas beyond their daily jobs (Deichmann and van den Ende, 2014) will share their knowledge. Knowledge sharing refers to the transfer of knowledge acquired by an individual to others (Liu and Liu, 2008). Knowledge sharing enables employees to share their experience and dialogues, to build ideas and to explore sources of innovation (Lawson and Samson, 2001). Employees who are motivated to submit ideas will increase the frequency, as well as the quantity, of the ideas they submit (Deichmann and Stam, 2015). Using the concept of the depth of knowledge sources (Laursen and Salter, 2006), we argue that the frequency and the quantity of submitted ideas represent the number of internal knowledge sources that have a high intensity interaction with the firm. Furthermore, the main purpose of leveraging ideas from employees is to improve business processes and practices within the organisation (Deichmann and Stam, 2015). Based on this argument, we conclude that the depth of internal knowledge sources will improve the capability of the firm to innovate.

To conduct innovation activities, firms use not only internal knowledge, but also external knowledge. In this study, we use the Resource Dependency Theory (RDT), which states that a firm requires resources, particularly from external knowledge sources, in order to survive (Pfeffer and Salancik, 2003). RDT also claims that a firm collaborates with external partners to get external knowledge via its various collaborations, such as joint ventures, alliances, mergers and acquisitions (Hillmanet al., 2009). Collaborations involve various actors, such as customers, suppliers, competitors, consultants, universities, and government offices (see Laursen and Salter, 2006; Chiang and Hung, 2010; Indarti, 2010).

Collaborations with various external knowledge sources are important to access knowledge and to enhance innovation capabilities (CameloOrdaz et al., 2009). Knowledge from external sources offers newer knowledge than that from internal sources (Liu and Liu, 2008). Increasing the quantity of new knowledge will improve the possibilities of finding a new useful combination of knowledge (Katila and Ahuja, 2002). Amara and Landry (2005) stated that various sources of information from markets are useful for conducting incremental innovation. More specifically, the breadth of the external knowledge sources is beneficial to supporting radical innovation (Chiang and Hung, 2010).

Previous studies (e.g. Katila and Ahuja, 2002; Laursen and Salter, 2006; Chiang and Hung, 2010; Henttonen and Ritala, 2013) showed the association between the breadth and the depth of external knowledge and their effects 
on the innovation capabilities within a firm. The deeper and wider the interaction between a firm and its knowledge sources is, the higher the innovation capabilities will be (Laursen and Salter, 2006; Chiang and Hung, 2010; Henttonen and Ritala, 2013). Firms can increase their capabilities to innovate by absorbing more knowledge (Katila and Ahuja, 2002).

Moreover, various sources of knowledge, such as from internal and external sources of the firm, can be useful for a firm's innovation. According to previous studies, the presence of various knowledge sources reflects the amount of knowledge sources that were studied using the concept of an open innovation (e.g. Amara and Landry, 2005; Laursen and Salter, 2006). Laursen and Salter (2006) then introduced the concept of the breadth and depth of knowledge sources, to study the amount of knowledge sources. The breadth of knowledge sources refers to the amount of knowledge sources used within a firm. The depth of knowledge sources is the amount of high intensity knowledge sources used by a firm (Laursen and Salter, 2006).

The current study focuses on examining the effect of the amount of knowledge sources on innovation, with special reference to restaurants and cafés in Indonesia, which are also categorised as being part of the culinary sector. The restaurants business has been referred to as an uncertain undertaking (Muller, 1999) due to several factors (see Alonso and Krajsic, 2014), such as competition (Altinay, 2010), high labour costs (Alexakis, 2011), increasing government regulations (Sharma and Christie, 2010), the adoption of technology (Wang and Qualls, 2007) and change (Brownell, 2008). This level of uncertainty contributes to the level of complexity faced by the managements of restaurant businesses. Uncertainty and complexity imply the importance of knowledge for the managers and owners of restaurants and cafés. Sources of knowledge can be from internal (i.e. chef and front liner) as well as external (i.e. customers, suppliers, and associations) sources (Ottenbacher and Harrington, 2007). From the contextual aspect, restaurants and the culinary sector in Indonesia have experienced a higher growth rate
(1.48 percent) than other sectors in the creative industry sector ( 0.98 percent) (see The Ministry of Tourism and Creative Economy, 2014). The culinary sectors growth rate is also higher than the national average (1.05 percent) (see The Ministry of Tourism and Creative Economy, 2014). Such higher growth in the culinary subsector is because of a lower barrier to enter this industry (The Ministry of Tourism and Creative Economy, 2015). The low level of the entry barrier stimulates firms to sustain through innovation. Therefore, a study on the effect of knowledge sources in the setting of the restaurant business is relevant.

\section{RESEARCH PROBLEM}

This study is intended to fill several gaps in earlier studies. Firstly, the vast majority of studies into the breadth and depth of knowledge sources used the perspective of open innovation to investigate the external knowledge sources (e.g. Laursen and Salter, 2006; Chiang and Hung, 2010; Henttonenet al., 2011). Many of those previous studies had uncovered the impact of the breadth and depth of internal knowledge sources on the innovation capabilities, while the internal R\&D was neglected (see Laursen and Salter, 2006). In fact, the internal knowledge sources are not identical with the internal R\&D. Van de Vrande et al.(2009) claimed that the role of employees (beyond internal $R \& D$ ) is significant for open innovation activities.

Secondly, we found that the empirical studies on the effect of the breadth and depth of the external knowledge sources on innovation capabilities are still inconclusive. Laursen and Salter (2006) stated that the breadth and depth of the external knowledge sources are curvilinear of the innovation capabilities. They argue that the breadth and depth of external knowledge sources have positive as well as negative consequences on the innovative capabilities. A study by Chiang and Hung (2010) showed that the breadth and depth of external knowledge sources have positive significant effects on the innovation capabilities. Accessing a large number of external knowledge sources and maintaining contact with them can facilitate 
access to new knowledge and to innovation (Chiang and Hung, 2010).

Thirdly, previous studies on the breadth and depth of knowledge are predominantly conducted in manufacturing firms (e.g. Katila and Ahuja, 2002; Chiang and Hung, 2010) and used Community Innovation Survey (CIS) data (e.g. Laursen and Salter, 2006; Henttonen and Ritala, 2013). Few studies were conducted in the context of service firms (e.g. Salgeet al., 2013). In fact, foodservice firms such as restaurants and cafés also leverage ideas from internal and external knowledge sources (Ottenbacher and Harrington, 2007). From a firm's internal point of view, ideas are from the back-of-house (chefs) and front-of-house staff (waiters, cashiers) (Harrington and Ottenbacher, 2013). From a firm's external point of view, external ideas are from customers, competitors, channel members, trade associations and exhibitions, and cooking literature (Ottenbacher and Harrington, 2007). Furthermore, service firms (e.g. restaurants and cafés) have different characteristics compared to manufacturers.

\section{QUESTIONS AND OBJECTIVE OF THE RESEARCH}

Based on the above mentioned discussion, the current study is aimed at examining the effect of the breadth of the depth of knowledge sources (i.e. internal and external) on innovation capabilities. The main question of the study is what is the effect of the internal and external knowledge on a firm's innovation capabilities? Additionally, we aim to answer the following questions. a) What knowledge sources are mainly used? b) What type of innovation is frequently conducted? To be more precise, the internal and external knowledge are measured using the breadth and the depth of the knowledge sources.

\section{THEORETICAL FRAMEWORK}

\section{Resource-based View and Knowledge- based View}

Innovation is conducted by a firm to achieve a sustained competitive advantage (Johannessen $e t$ $a l ., 2001)$. Based on the resource-based view, '... a firm is said to have a sustained competitive advantage when it is creating more economic value than the marginal firms in its industry and when other firms are unable to duplicate the benefits of this strategy'(Barney and Clark, 2007:52). Then, Barney (1991:105-106) also stated '... not all firm resources hold the potential of sustained competitive advantages. To have this potential, firm resources must meet four conditions (a) it must be valuable, in the sense that it exploits opportunities and/or neutralises threats in its firm's environment, (b) it must be rare among a firm's current and potential competition, (c) it must be imperfectly imitable, and (d) there cannot be strategically equivalent substitutes for this resource that are valuable but neither rare or imperfectly imitable'. Resourcesbased View (RBV) can be applied to understand whether these firms will gain a competitive advantage, how sustainable this competitive advantage is likely to be, and what the sources of the competitive advantage are (Barney, 2007).

The resources covered by the resourcesbased view are the internal resources in firms, such as assets, capabilities, organisational processes, firm attributes, information, knowledge, etc. (Daft, 1983, in Barney, 1991). Knowledge, as the part of the operant resources, can also be explained by the Knowledge-based View (KBV), which emphasises the importance of knowledge as a resource of the firms (Grant, 1996). As a resource of the firms, knowledge creates the value of the firm and supports its invention, efficiency and productivity (Ziesemer, 2013). By utilising knowledge within the firm, knowledge can be used as a source for innovation (Tidd and Bessant, 2009).

\section{Resource Dependency Theory}

A firm acquires resources (i.e. knowledge) from the outside because it has limited resources (see Paridaet al., 2012). Pfeffer and Salancik (1978) introduced the concept "Resource Dependency Theory (RDT)", which explains that a firm requires resources to survive in its chosen environment (Pfeffer and Salancik, 2003). Using RDT, Hillman et al., (2009) confirmed that a 
firm which has limited resources will collaborate with external partners. RDT is also used by academicians to explain the many kinds of collaboration among the firms (Drees and Heugens, 2013), such as joint ventures, alliances, R\&D collaborations, research collaborations, joint marketing agreements, and the relationship between buyers and sellers (Hillman et al., 2009). Collaborations are conducted with many external knowledge sources such as customers, suppliers, competitors, consultants, universities and the government (see Laursen and Salter, 2006; Indarti, 2010).

\section{Knowledge}

Knowledge is the essential resource (Grant, 1996; Carneiro, 2000; Liaoet al., 2007) that can determine the sustainability of the competitive advantage of a firm (Caloghirou et al., 2004). Knowledge is also considered to be the key to innovation (Liao et al., 2007). From the knowledge management literature, knowledge is classified into types of knowledge and sources of knowledge. Based on the knowledge types, Michael Polanyi (1966) distinguished knowledge as either tacit or explicit knowledge (Kale, 2012). Tacit knowledge is personal knowledge which is difficult to transfer. On the other hand, explicit knowledge is formal knowledge that is easy to communicate and share (Nonaka, 1991). Although tacit knowledge is difficult to communicate, each type of knowledge can be transformed into other types. Their transformation is then represented by a SECI model consisting of Socialisation, Externalisation, Centralisation and Internalisation (Nonaka, 1991).

Knowledge used for innovation activities can be from inside and outside the firm (see Van den Endeet al., 2014). Knowledge is obtained from employees (Elche-Hotelano, 2011) and the owner of the firm (Indarti, 2010), who are known as the internal knowledge sources, whilst the knowledge from outside is the combination of knowledge from external partners, called the external knowledge sources (Laursen and Salter, 2006). To understand both knowledge sources,
Table 1 shows a detailed explanation of the knowledge's sources.

The use of specific sources of knowledge is important for paticular innovations (Van Geenhuizen and Indarti, 2005). However, '... it was not sufficient to look independently at the various sources of information because the development and improvement of products and processes cannot depend only on one source of information, but they must rely on recourse to a variety of sources of information' (Amara and Landry, 2005:250). This is in line with the concept of the breadth and depth of knowledge sources from Laursen and Salter (2006). The breadth of knowledge refers to the number of knowledge sources used by firms, and the depth of knowledge sources represents the number of knowledge sources used intensively by the firms.

\section{Innovation}

Innovation is a multidimensional concept and is defined as 'creating something new' (Tidd and Bessant, 2009:6). The literature on innovation management classified innovation into five aspects: purpose, process, output, newness and capability.

\subsection{Innovation as a purpose}

Innovation as a purpose can be seen from a macro and a micro perspective. From a macro perspective, innovation is related to the national economy of a country. Innovation is a way to improve the growth of a nation's economy (Tidd and Bessant, 2009; Vrgovicet al., 2012). On the other hand, the micro perspective emphasises that innovation is the main thing for a firm to achieve a sustained competitive advantage (Johannessenet al., 2001; Akman and Yilmaz, 2008).

\subsection{Innovation as a process}

Two main views to categorise innovation as a process are: 1) innovation value chain (Hansen and Birkinshaw, 2007), and 2) initiation and implementation of innovations (Rogers, 2003). In this perspective, innovation begins at the ideas generation stage (Hansen and Birkinshaw, 2007) or initiation (Rogers, 2003), onwards to 
Table 1 Knowledge sources

\begin{tabular}{|c|c|}
\hline Knowledge Sources & Reference \\
\hline \multicolumn{2}{|l|}{ INTERNAL } \\
\hline Owners & Romijn andAlbaladejo (2002); Indarti (2010) \\
\hline \multicolumn{2}{|l|}{ Back of House } \\
\hline $\begin{array}{l}\text { Manager and staff (i.e. } R \& D \text {, production, } \\
\text { human resource, financial, marketing) }\end{array}$ & $\begin{array}{l}\text { Amara andLandry (2005); Tidd and Bessant (2009:115); } \\
\text { Huang and Rice (2012); Harrington and Ottenbacher (2013) }\end{array}$ \\
\hline \multicolumn{2}{|l|}{ Front of House } \\
\hline Waiters/Servers and Cashiers & Ottenbacher and Harrington (2007) \\
\hline \multicolumn{2}{|l|}{ EXTERNAL } \\
\hline \multicolumn{2}{|l|}{ Direct-Individual } \\
\hline Customers & $\begin{array}{l}\text { Harrington (2004); Indarti (2010); Najib andKiminami (2011); } \\
\text { Salge et al. (2013) }\end{array}$ \\
\hline Suppliers & $\begin{array}{l}\text { Van Geenhuizen and Indarti (2005); Indarti (2010); Harrington } \\
\text { and Ottenbacher (2013) }\end{array}$ \\
\hline Competitors & Harrington (2004); Indarti (2010); Najib and Kiminami (2011) \\
\hline Consultants & Indarti (2010) \\
\hline \multicolumn{2}{|l|}{ Direct-Institutional } \\
\hline Universities & Laursen and Salter (2004); Indarti (2010) \\
\hline Government officers & Van Geenhuizen andIndarti (2005); Indarti (2010) \\
\hline Industry associations & Van Geenhuizen and Indarti (2005); Indarti (2010) \\
\hline \multicolumn{2}{|l|}{ Indirect } \\
\hline Exhibitions & Van Geenhuizen andIndarti (2005); Indarti (2010) \\
\hline $\begin{array}{l}\text { Magazines/newspapers; televisions; radios; } \\
\text { internet }\end{array}$ & Van Geenhuizen andIndarti (2005); Indarti (2010) \\
\hline Books/literature & Ottenbacher and Harrington (2007) \\
\hline
\end{tabular}

the implementation of the idea. In the process of generating an idea, knowledge from various sources is absorbed (Tidd and Bessant, 2009), and transformed into new products/services or value-added activities (Roper et al., 2008). Similarly, Rogers (2003) argued that in the initiation stage, all the information is gathered, conceptualised, and planned for the adoption of an innovation, leading up to the decision to adopt. Then, the process will be continued by events, actions, and decisions in putting the innovation into use, which is called the implementation stage.

\subsection{Innovation as an output}

Schumpeter (1934:66) classified innovation as '1) the introduction of a new good ...; 2) the introduction of a new production method ...;3) the opening of a new market ...; 4) the opening of a new source of supply ...; 5) the implementation of a new organisation for any industry ....' This classification is known as innovation outputs (see Ganotakis and Love, 2012). In more detail, from the literature on innovation, the outputs of innovation can be product innovation, service innovation, process innovation, market innovation, logistic innovation and organisational innovation, as summarised in Table 2.

\subsection{Innovation as a newness}

From the newness or degree of change, innovation is generally categorised as either radical or incremental innovation. Rogers (2003) defined radical innovation as major changes that are often presented in a new paradigm; while incremental innovation is similar to a modification, development, consolidation and/or improvement (Gaynor, 2002). 
Table 2 Types of innovation output

\begin{tabular}{ll}
\hline \multicolumn{1}{c}{ Type } & \multicolumn{1}{c}{ Description } \\
\hline Product innovation & Changes or improvement in products \\
Service innovation & $\begin{array}{l}\text { Changes or improvement in the way to serve the product } \\
\text { Process innovation }\end{array}$ \\
Market innovation & $\begin{array}{l}\text { Changes or improvement in methods of production (i.e. new technologies) } \\
\text { pricing) }\end{array}$ \\
Logistic innovation & $\begin{array}{l}\text { Changes or improvement in logistics (i.e. raw material, suppliers, packaging, } \\
\text { delivery methods) } \\
\text { Changes or improvement in organisational practices, process, and structure }\end{array}$ \\
\hline
\end{tabular}
Source: Neely et al. (2001); Avermaete et al. (2003); van Geenhuizen and Indarti (2005); Birkinshaw et al. (2008)

Radical and incremental innovations are related to exploration and exploitation (see Benner and Tushman, 2003). March (1991:71) explained that exploration includes things captured by terms such as search, variation, risk taking, experimentation, play, flexibility, discovery, innovation. Exploitation includes such things as refinement, choice, production, efficiency, selection, implementation and execution. Benner and Tushman (2003) stated that exploration is related to radical innovation, but incremental innovation is closer to exploitation. From the perspective of risk, incremental innovation had fewer risks than radical innovation (Rogers, 2003).

\subsection{Innovation as a capability}

Innovation has a capability to understand and respond to its external environment (Akman and Yilmaz, 2008). The form of a firm's capability to innovate can be viewed as how it introduces a new product, a new process, and new ideas (Koc and Ceylan, 2007). Innovation capability is closely related to the capability of a firm to utilise knowledge (Subramaniam and Youndt, 2005). That knowledge is obtained from internal and external sources (Caloghirou et al., 2004; Elche-Hotelano, 2011). Knowledge from the internal sources is explained by RBV and KBV. On the other hand, RDT is used to explain the knowledge from external sources. Innovation capability is also related to the capability of a firm to integrate, build, and configure its internal and external competencies to respond to changes in its external environment (Parashar and Singh, 2005).

\section{HYPOTHESIS DEVELOPMENT}

\section{The Effect of Internal Knowledge's Sources on Innovation Capabilities}

Knowledge from internal sources is obtained from employees (Elche-Hotelano, 2011) and owners (Indarti, 2010). Firms can leverage new ideas from employees by having a suggestions system, in which the employees transferred their ideas to support innovations by their firms (Van Djik and Van den Ende, 2002). The owner of the firm is considered to be the decision maker for innovation, who provides his or her knowledge for conducting the innovations (Indarti, 2010).

The employees and owners whose knowledge is used to develop innovations represent the variety of the sources of the knowledge (Amara and Landry, 2005). Using the concept by Laursen and Salter (2006), the breadth of internal knowledge sources is defined as the variety of the internal knowledge sources. Amara and Landry (2005) found that Canadian firms used a large variety of internal knowledge sources to develop innovations. We may conclude that the breadth of the internal knowledge sources has a positive effect on innovation capabilities.

Employees who take the initiative and provide new ideas for things outside their daily jobs (Deichmann and Van den Ende, 2014) share their knowledge. Knowledge sharing refers to the transfer of knowledge acquired by one individual to others (Liu and Liu, 2008). Knowledge sharing will enable employees to share their experiences, hold a dialogue with others and build ideas to explore the innovation 
sources (Lawson and Samson, 2001). Employees who are motivated to submit ideas will increase their frequency of submitting ideas and the quantity of ideas they generate (Deichmann and Stam, 2015). Using the concept of the depth of knowledge sources (Laursen and Salter, 2006), we argue that the frequency and the quantity of ideas generated, as represented by the number of internal knowledge sources, will contribute to the high intensity interactions within the firm. Furthermore, the purpose of leveraging ideas from employees is to improve the business processes and practices within the organisation. By doing so, the capability of a firm to innovate will be increased (Deichmann and Stam, 2015). Based on this argument, we formulate the following hypotheses on internal knowledge sources:

Hla: Breadth of internal knowledge sources is positively related to the innovation capability

H1b: Depth of internal knowledge sources is positively related to the innovation capability

\section{The Effect of External Knowledge Sources on Innovation Capabilities}

A firm collaborates with many external sources, such as its customers, suppliers, competitors, consultants, university staff, and government officials (see Laursen and Salter, 2006; Indarti, 2010). These collaborations between a firm and other external sources indicate the variety of external knowledge sources, called the breadth of the external knowledge sources (Laursen and Salter, 2006).

Collaborating with a variety of external knowledge sources is important to access external knowledge and to enhance the innovation capabilities (Camelo-Ordazet al., 2009). External sources offer more up-to-date knowledge than internal ones do (Liu and Liu, 2008). The updated or new knowledge will improve the possibility of the firm finding a new, useful combination of knowledge (Katila and Ahuja, 2002). A study by Amara and Landry (2005) also supported the idea that a variety of sources of information from the market (i.e. the external side) are useful when implementing incremental changes. Additionally, Chiang and Hung (2010) also concluded that the breadth of external knowledge sources support radical innovation within a firm.

The breadth of the external knowledge sources is followed by the depth of them (Laursen and Salter, 2006). From the literature on knowledge management, we conclude that the more external knowledge sources that are involved, the higher is the interaction occurring within the firm and the more innovations are conducted (Chiang and Hung, 2010; Henttonen and Ritala, 2013). Katila and Ahuja (2002) also argue that the increased capabilities of a firm to innovate are dependent on the capability of the firm to recognise and understand its knowledge (Katila and Ahuja, 2002). So, the deeper and broader that the knowledge is from the external sources, the higher the innovation capabilities are, hence two hypotheses are stated as follows:

H2a: Breadth of external knowledge sources is positively related to the innovation capability

H2b: Depth of external knowledge sources is positively related to the innovation capability

\section{METHODOLOGY}

\section{Characteristics of Respondents and Firms}

Among the 101 owners/managers of the restaurants and cafés, 75 percent of them are male and almost 50 percent of them are in the productive age group (25-35 years old). The vast majority of the respondents have working experience (90 percent), and 39.60 percent graduated from university (see Table 3 ). From the demographic aspects of the firms, 51.49 percent of the restaurants and cafés were established within the last five years and the majority of them $(62.38$ percent $)$ are independently owned. Most (80 percent) of the restaurants and cafés in this study have between 10 and 100 employees, which means they can be considered to be SMEs. The majority of the firms in this study were started by the owner (51.49 percent) or the family (26.73 percent). 
The owners and the family also actively managed the firm (11.88 percent for owner, and 22.77 percent for families, respectively), as shown in Table 4.

Table 3 Demographic aspects of the respondents

\begin{tabular}{|c|c|c|c|}
\hline \multicolumn{2}{|c|}{ Demographic Aspects } & $\mathbf{N}$ & $\%$ \\
\hline \multicolumn{4}{|c|}{ Gender } \\
\hline . & Male & 76 & $75.25 \%$ \\
\hline- & Female & 25 & $24.75 \%$ \\
\hline \multicolumn{4}{|l|}{ Age } \\
\hline - & $<25$ years & 14 & $13.86 \%$ \\
\hline- & $25-30$ years & 36 & $35.64 \%$ \\
\hline- & $31-35$ years & 20 & $19.80 \%$ \\
\hline- & $36-40$ years & 15 & $14.85 \%$ \\
\hline- & $41-45$ years & 8 & $7.92 \%$ \\
\hline . & $46-50$ years & 5 & $4.95 \%$ \\
\hline- & $>51$ years & 3 & $2.97 \%$ \\
\hline \multicolumn{4}{|c|}{ Educational level } \\
\hline- & Senior High School & 35 & $34.65 \%$ \\
\hline- & Diploma & 20 & $19.80 \%$ \\
\hline- & Bachelor degree & 40 & $39.60 \%$ \\
\hline- & Master degree & 6 & $5.94 \%$ \\
\hline \multicolumn{4}{|c|}{ Position } \\
\hline- & Owner & 18 & $17.82 \%$ \\
\hline- & General Manager & 20 & $19.80 \%$ \\
\hline- & Manager & 43 & $42.57 \%$ \\
\hline - & Staff/Supervisor & 20 & $19.80 \%$ \\
\hline \multicolumn{4}{|c|}{ Working experience } \\
\hline- & Yes & 91 & $90.10 \%$ \\
\hline- & Never & 18 & $9.90 \%$ \\
\hline
\end{tabular}

Table 4 Demographic aspects of the firms

\begin{tabular}{|c|c|c|c|}
\hline & nographic Aspects & $\mathbf{N}$ & $\%$ \\
\hline \multicolumn{4}{|c|}{ Firm age } \\
\hline . & $<2$ years & 14 & $13.86 \%$ \\
\hline & $2-5$ years & 35 & $34.65 \%$ \\
\hline - & $>5$ years & 52 & $51.49 \%$ \\
\hline \multicolumn{4}{|c|}{ Ownership } \\
\hline - & Independent & 63 & $62.38 \%$ \\
\hline - & Branch & 29 & $28.71 \%$ \\
\hline - & Franchise & 10 & $9.90 \%$ \\
\hline \multicolumn{4}{|c|}{ Labor } \\
\hline & $<10$ people & 6 & $5.94 \%$ \\
\hline- & $10-30$ people & 50 & $49.50 \%$ \\
\hline - & $30-100$ people & 43 & $42.57 \%$ \\
\hline - & $>100$ people & 2 & $1.98 \%$ \\
\hline \multicolumn{4}{|c|}{ Initiator } \\
\hline - & Owner & 52 & $51.49 \%$ \\
\hline - & Family & 27 & $26.73 \%$ \\
\hline - & Colleagues/Friends & 5 & $4.95 \%$ \\
\hline - & Collaboration & 17 & $16.83 \%$ \\
\hline
\end{tabular}

\begin{tabular}{crr}
\hline Demographic Aspects & N & \multicolumn{1}{c}{$\%$} \\
\hline Management & 12 & $11.88 \%$ \\
- Owner & 23 & $22.77 \%$ \\
- $\quad$ Family & 7 & $6.93 \%$ \\
- Colleagues/Friends & 10 & $9.90 \%$ \\
- $\quad$ Collaboration & 23 & $22.77 \%$ \\
- $\quad$ Employee & 23 & $22.77 \%$ \\
- Owner and employee & 3 & $2.97 \%$ \\
\hline
\end{tabular}

\section{Respondents, Sampling Technique and Research Site}

The respondents of this study are the owners or the managers of restaurants and cafés in Indonesia. According to the data from the Ministry of Tourism and Creative Economy (2014), the majority (70 percent) of Indonesian restaurants and cafés are located in Java, Indonesia, particularly in big cities such as Jakarta, Bandung, Surabaya, and outside of Java in places such as Bali. Additionally, restaurants and cafés in Indonesia are mainly located in tourist destination such as Bali and Yogyakarta (see travel.detik.com, 2012; travelesia.com, 2014; $\quad$ kuliner.panduanwisata.id, 2015; surgatraveller.com, 2015). Based on the distribution of restaurants and cafés in Indonesia and the researchers' accessibility, we selected Bandung, Bali, Bogor, Malang, Surabaya and Yogyakarta as our main research sites. To increase the response rate, we also include other cities in East Java.

A purposive sampling technique was used to select the respondents. We selected restaurants and cafés that have been operating for at least one year to ensure that they had been dealing with various knowledge sources. Branch outlets of the restaurants and cafés were not included, since their owner or manager is already one of our respondents and would provide the same information again. The main survey to collect the data was conducted in 2015.

\section{The Instrument and its Quality}

The main instrument of the study is a questionnaire, which was developed from previous studies (see Table 5). The questionnaire consists of three parts 1) personal data of the 
respondent and the firm, 2) innovation activities of the firm and 3) knowledge sources. The instruments were developed based on the previous studies (e.g. Hadjimanolis, 2000; Johannessen et al., 2001; Laursen and Salter, 2006; Indarti, 2010; Harrington and Ottenbacher, 2013; Romijn and Albaladejo, 2002). We conducted a judgment and content validity to ensure that the instrument had adequate coverage of the investigative questions guiding the study (Cooper andSchindler, 2014). A pilot test of the questionnaire was conducted to ensure the quality of the instrument in terms of its language, context and the relevance of the questions.

\section{FINDINGS}

\section{Innovation Capabilities}

In this study, the innovation capabilities were measured by the degree of newness (radical and incremental innovation) and the innovation outputs (product, service, process, market, logistic and organisational innovation). As shown in Table 6 , product innovation was frequently $\left(\right.$ mean $_{\text {product-radical }}=3.08 ;$ mean $_{\text {product- }}$ incremental $=3.46)$ conducted by the Indonesian restaurants and cafés, followed by service innovations $\left(\right.$ mean $_{\text {service-radical }}=2.75$; mean $_{\text {service- }}$ incremental $=3.12$ ) and market innovations $\left(\right.$ mean $_{\text {market-radical }}=2.49 ;$ mean $_{\text {market-incremental }}=$ 2.94). The nature of the restaurants and cafés, which mainly produce tangible products, such as various food and drinks, may explain the findings.

Furthermore, we conducted a paired sample $t$-test, to compare the level of newness (radical and incremental innovation) as shown in Table 6. In general, the findings show that the firms conducted more innovation at the incremental level, rather than the radical level. More specifically, the Indonesian restaurants and cafés production of incremental product innovations $\left(\right.$ mean $\left._{\text {product-incremental }}=3.46\right)$ is significantly higher than $\left(t_{\text {product-innovation }}=-2.94 ; p<0.05\right)$ that of the radical ones $\left(\right.$ mean $\left._{\text {product-radical }}=3.08\right)$ (see Table 6). Similar findings also applied to their service innovation, market innovation, and organizational innovation. For example, in the context of incremental product innovations, firms only modified the taste of their various existing dishes, such as fried noodles with seafood, beef, pork, or vegetables.

Table 5 Operational variables

\begin{tabular}{|c|c|c|c|c|}
\hline No. & Variable & Definition & Item & Instrument \\
\hline 1. & $\begin{array}{l}\text { Innovation } \\
\text { capabilities }\end{array}$ & $\begin{array}{l}\text { Capability of the firms to } \\
\text { transform knowledge to } \\
\text { innovative outputs }\end{array}$ & 25 & $\begin{array}{l}\text { Johannessen } \text { et al. (2001); Indarti } \\
\text { (2010) }\end{array}$ \\
\hline 2. & $\begin{array}{l}\text { Breadth of internal } \\
\text { knowledge sources }\end{array}$ & $\begin{array}{l}\text { Number of internal knowledge } \\
\text { sources that submit their ideas }\end{array}$ & 14 & $\begin{array}{l}\text { Amara and Landry (2006); Romijn } \\
\text { and Albaladejo (2002); Indarti } \\
\text { (2010); Harrington and } \\
\text { Ottenbacher (2013) }\end{array}$ \\
\hline 3. & $\begin{array}{l}\text { Depth of internal } \\
\text { knowledge sources }\end{array}$ & $\begin{array}{l}\text { Frequency and quantity of } \\
\text { internal knowledge sources that } \\
\text { submit their ideas }\end{array}$ & 14 & $\begin{array}{l}\text { Amara and Landry (2006); Romijn } \\
\text { and Albaladejo (2002); Indarti } \\
\text { (2010); Harrington and } \\
\text { Ottenbacher (2013) }\end{array}$ \\
\hline 4. & $\begin{array}{l}\text { Breadth of external } \\
\text { knowledge sources }\end{array}$ & $\begin{array}{l}\text { Number of external knowledge } \\
\text { sources that submit their ideas }\end{array}$ & 13 & $\begin{array}{l}\text { Laursen and Salter (2006); Indarti } \\
\text { (2010) }\end{array}$ \\
\hline 5. & $\begin{array}{l}\text { Depth of external } \\
\text { knowledge sources }\end{array}$ & $\begin{array}{l}\text { Frequency and quantity of } \\
\text { external knowledge sources } \\
\text { that submit their ideas }\end{array}$ & 13 & $\begin{array}{l}\text { Laursen andSalter (2006); Indarti } \\
\text { (2010) }\end{array}$ \\
\hline
\end{tabular}

Notes: All items are measured using 5-point Likert scale. 
Table 6 Innovation outputs

\begin{tabular}{|c|c|c|c|c|c|c|}
\hline \multirow{2}{*}{ No. } & \multirow{2}{*}{ Innovation Type } & \multicolumn{2}{|c|}{ Radical } & \multicolumn{2}{|c|}{ Incremental } & \multirow[b]{2}{*}{$t$} \\
\hline & & Mean & SD & Mean & SD & \\
\hline 1 & Product innovation & 3.08 & 1.20 & 3.46 & 1.04 & $-2.94 * *$ \\
\hline 2 & Service innovation & 2.75 & 1.31 & 3.12 & 1.15 & $-2.92 * *$ \\
\hline 3 & Process innovation & 2.11 & 1.28 & 2.10 & 1.31 & 0.10 \\
\hline 4 & Market innovation & 2.49 & 1.39 & 2.94 & 1.38 & $-3.31 * *$ \\
\hline 5 & Logistic innovation & 1.95 & 1.25 & 2.14 & 1.23 & -1.45 \\
\hline 6 & Organisational innovation & 1.00 & 0.00 & 2.16 & 1.29 & $-9.00 * *$ \\
\hline
\end{tabular}

\section{Breadth and Depth of Knowledge Sources}

The breadth of knowledge refers to the number of knowledge sources-internal and external sources-that submitted their ideas. The depth of knowledge sources represents the frequency and quantity of the knowledge sources. We found that the Indonesian restaurants and cafés deal more frequently with the external, rather than the internal, knowledge sources. As seen from Figure 1, the Indonesian restaurants and cafés reported that the main internal knowledge sources are from their owners (86.14 percent), followed by the operations managers (64.36 percent), and production staff (52.48 percent). On the other hand, the customers (90.10 percent), the Internet (79.21 percent), and books/literature (51.49 percent) are the most frequent and intense source of external knowledge used by the Indonesian restaurants and cafés (see Figure 2). The nature of the restaurants and cafés, which are mainly focused on producing food and beverages, as well as delivering their service directly to their customers, may be an explanation for this.

We also conducted an independent sample ttest to compare the presence of the internal and external sources of knowledge used by the respondents. We found that the breadth of external knowledge sources $\left(\right.$ mean $\left._{\text {external }}=4.28\right)$ is significantly higher $(t=-2.08 ; p<0.05)$ than that of the internal ones (see Table 7).The findings indicate that the external knowledge sources are more often used than the internal ones. Meanwhile, the depths of the sources of external knowledge and internal knowledge are not significant.

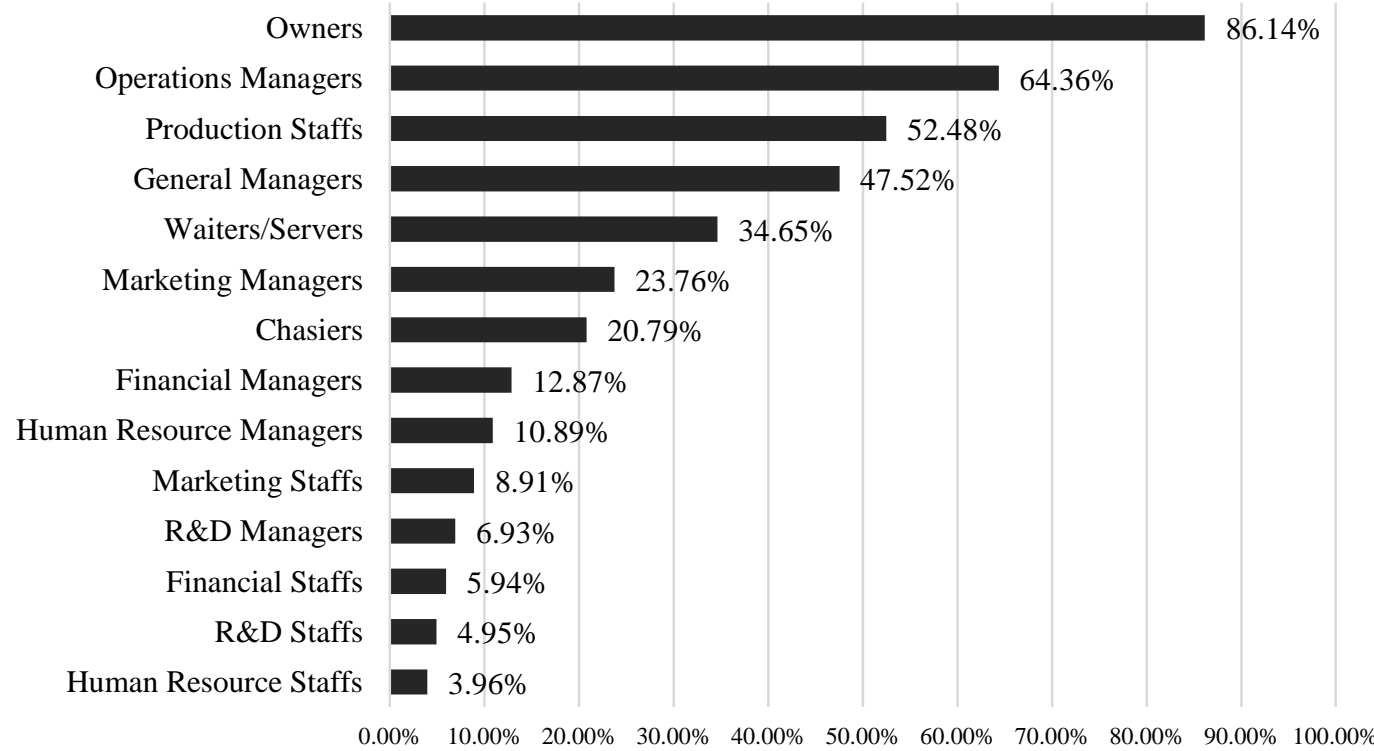

Note: *Multiple answers are allowed

Figure 1 Internal knowledge sources 


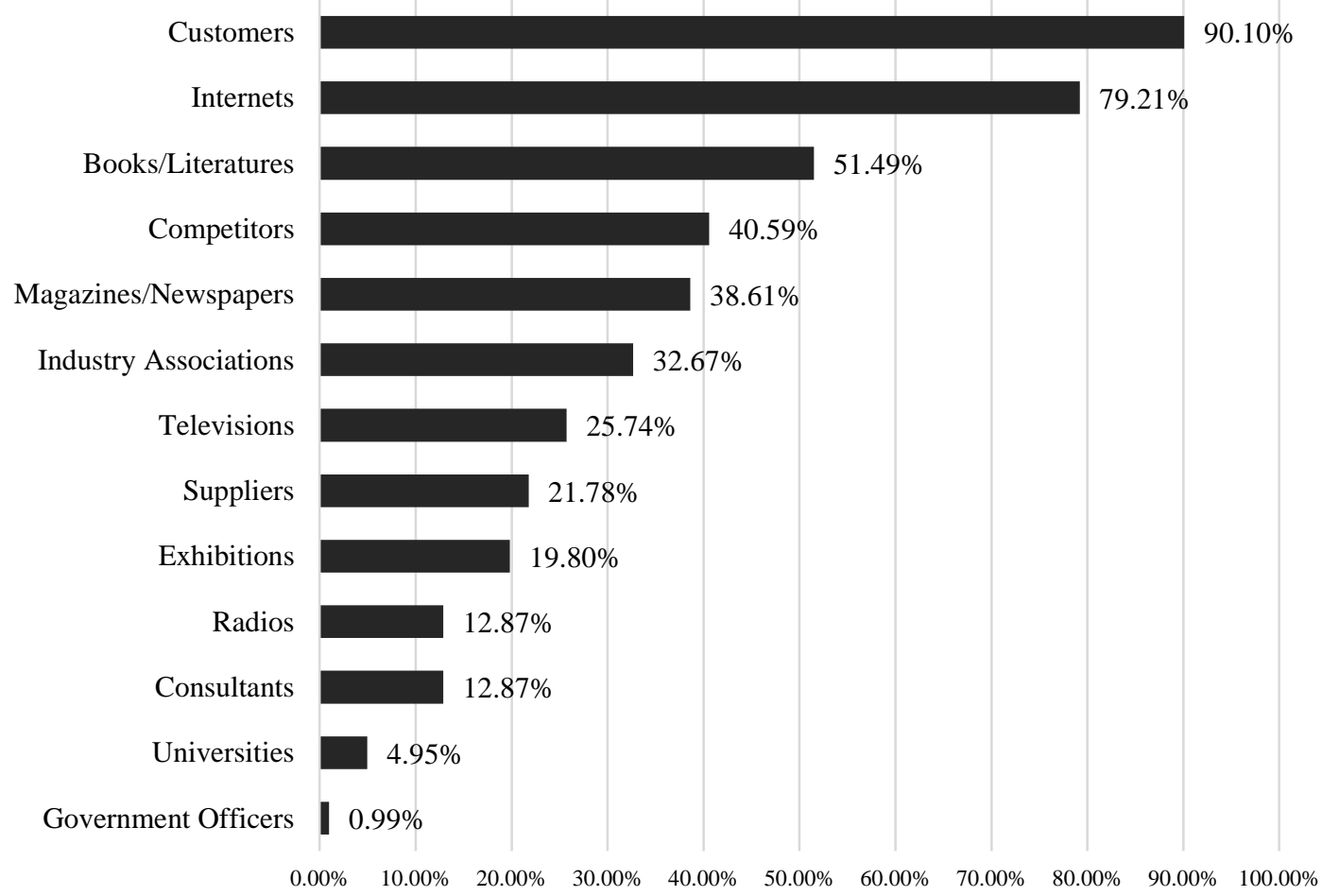

Note: *Multiple answers are allowed

Figure 2 External knowledge sources

Table 7 Knowledge sources

\begin{tabular}{|c|c|c|c|c|}
\hline & & Mean & SD & $t$ \\
\hline \multirow[b]{2}{*}{ Breadth } & Internal knowledge sources & 3.73 & 1.65 & \multirow[b]{2}{*}{$-2.08 * *$} \\
\hline & External knowledge sources & 4.28 & 2.05 & \\
\hline \multirow{2}{*}{ Depth } & Internal knowledge sources & 0.65 & 0.89 & \multirow{2}{*}{-0.21} \\
\hline & External knowledge sources & 0.68 & 1.09 & \\
\hline
\end{tabular}

\section{Hypotheses Testing}

To test the proposed hypotheses, we conducted a multiple regression as shown in Table 8. The findings show that only the depth of the internal knowledge sources has a significant effect on innovation capability $(\beta=0.11 ; t=2.01 ; p<$ 0.05). Meanwhile, the other three independent variables: the breadth of the internal and external knowledge sources and the depth of the external knowledge sources are found not to be significant.

As a result, the proportion of the total variance of the innovation capability is limited as indicated by a small $\mathrm{R}^{2}$. Hair et al. (2009), stated that the number of independent variables affects $\mathrm{R}^{2}$. Our intention is not to explain the total variance of the innovation capability by developing a complex model. Instead, we are interested in examining the effect of each independent variable. Hence, despite the small value of $R^{2}$, we can still claim that the findings provide proof that the depth of the internal knowledge sources has a significant impact on the innovation capabilities of the firms under examination. 
Table 8 Hypothesis testing

\begin{tabular}{lcc}
\hline \multicolumn{1}{c}{ Independent Variable } & $\boldsymbol{\beta}$ & $\boldsymbol{t}$ \\
\hline Breadth of internal knowledge sources & 0.01 & 0.37 \\
Depth of internal knowledge sources & 0.11 & $\mathbf{2 . 0 1 * *}$ \\
Breadth of external knowledge sources & 0.02 & 0.93 \\
Depth of external knowledge sources & 0.02 & 0.41 \\
\hline F & & \multicolumn{2}{c}{$\mathbf{2 . 1 7 ^ { * * * * }}$} \\
$\mathbf{R}^{\mathbf{2}}$ & & 0.08 \\
Adjusted $\mathbf{R}^{\mathbf{2}}$ & & 0.05 \\
\hline
\end{tabular}

Notes: The dependent variable is innovation capability

$*_{p}<0.01 ; * * p<0.05 ; * * * p<0.1$

\section{DISCUSSIONS AND CONCLUSIONS}

The current study explores the main types of innovation conducted and the main sources of knowledge utilized by restaurants and cafés in Indonesia. In terms of the innovation's output, product as well as service innovation are found to be the most frequent types of innovation conducted. Borrowing the classification of the strategic service matrix (see Metters et al., 2003), the restaurant and café business is a combination of tangible action and service, directed at people's bodies. This means that the restaurant and cafe business produces products as well as services. For instance, the restaurants or cafes may introduce new menu items (e.g. green tea, coffee-latte) and the same time, they also redesign their approach to their customers. Moreover, with regards to the degree of innovation, not surprisingly, the study found that incremental innovation is most preferred change adopted by the firms. This finding corroborates previous similar studies on innovation among furniture and software firms in Indonesia (e.g. van Geenhuizen and Indarti, 2005; Indarti, 2010).

The study also found the Indonesian restaurants and cafés absorb and utilise both internal and external sources of knowledge intensively. Owners, operations managers, and production staff are the most frequent sources of internal knowledge. From the external parties, the firms are very focused on absorbing knowledge from their customers, the Internet, and books/literature. However, we found that the sources for external knowledge are more often used than those for internal knowledge.
Interestingly, when we examined the effect of internal and external knowledge on innovation capability, the study found that only the depth of internal knowledge sources has a positive significant effect. The more frequently the internal sources of knowledge are used by the firms, the higher the innovation capability is. The more the Indonesian restaurants and cafés utilised the knowledge from their owners and employees (i.e. operations managers and production staff), the higher became the ability of the firms to innovate. This study confirms the previous studies (e.g. Amara and Landry, 2005; Elche-Hotelano, 2011) that claim the significant role of employees in conducting innovations within their firms. Additionally, this study also indicates that in the context of Small and Medium Enterprises (SMEs), the owners and managers are still the most influential people in the organisations (e.g. Stanworth and Curran, 1976).

However, the study does not support previous studies, for example Amara and Landry (2005), Laursen and Salter (2006), Chiang and Hung (2010), which reported that the external knowledge sources-in terms of their breadth and depth-and the breadth of internal knowledge source significantly increased the ability of a firm to innovate. As discussed previously, the basic characteristic of an SME is that it is highly dependent on the owner and its employees, which may explain the findings. Generally, the interaction between the owners of the firms and their managers or employee are very intense. These intensive interactions stimulate good communications among them-internal know- 
ledge sources, which encourages them to build innovative ideas for the firms (Lawson and Samson, 2001). This is in line with the Not Invented Here (NIH) syndrome that becomes an obstacle to a firm to accept knowledge from outside of it. The NIH syndrome usually makes internal persons not open to considering new ideas from external sources (Katz and Allen, 1982).

In addition to that, one of the problems with Indonesian SME's is their limited resources (e.g. capital or funding) to support activities within the firm -- (see Indarti and Langenberg, 2004), which hinders them when seeking knowledge from outside of their firm (Ferreras-Méndez $e t$ al., 2015; Laursen and Salter, 2006).

\section{LIMITATION AND FUTURE RESEARCH}

This study has some limitations, which can provide the opportunity for future research. Firstly, we measured the breadth and the depth of the knowledge sources in terms of their frequency and the quantity (e.g. Deichmann and Van den Ende, 2014; Deichmann and Stam, 2015). This means that our study did not capture their quality, which may be important and relevant for innovation (e.g. Verworn, 2009; Van den Endeet al., 2014). Future research may address this issue by adding the quality of the knowledge sources as a valuation of the depth of the knowledge sources.

Secondly, this study was conducted in the context of the SME restaurant and café business in Indonesia. We found that the sources of internal knowledge are mainly from the owners, operations managers, and production staff including the waiters/servers. This may indicate that the organisational structure of the firms are less complex than those found in other studies (e.g. Romijn and Albaladejo, 2002; Amara and Landry, 2005; Ottenbacher and Harrington, 2007). Taking the setting of a larger firm, which has a more complex organisational structure into account, may be relevant for any future agenda.

Thirdly, this study used a cross-section data system to examine the impact of knowledge sources on innovation capabilities. However, the nature of the process of generating ideas for innovation, up to the actual embodiment of the innovation, may consist of several stages (Van den Endeet al., 2014) and is a dynamic process. The current study is lacking in addressing this dynamic process of knowledge and innovation within firms. Future research should consider this issue by using longitudinal data (e.g. panel or data series) (see Henttonenet al., 2011).

\section{REFERENCES}

Akman, G., andYilmaz, C. 2008. "Innovative Capability, Innovation Strategy and Market Orientation: An Empirical Analysis in Turkish Software Industry". International Journal of Innovation Management, 12(1), 69-111.

Alexakis, G. 2011. "Transcendental Leadership: The Progressive Hospitality Leader's Silver Bullet". International Journal of Hospitality Management, 30(3), 708-713.

Alonso, D., and Krajsic, V. 2014. "Small Restaurant Businesses and The Importance of Knowledge of Cost Management: An Exploratory Study". International Journal of Leisure and Tourism Marketing, 4(1), 3149.

Altinay, L. 2010. "Market Orientation of Small Ethnic Minority-owned Hospitality Firms". International Journal of Hospitality Management, 29(1), 148-156.

Amara, N., and Landry, R. 2005. "Sources of Information as Determinants of Novelty of Innovation in Manufacturing Firms: Evidence from The 1999 Statistics Canada Innovation Survey". Technovation, 25 , 245259.

Avermaete, T., Viaene, J., Morgan, E., and Crawford, N. 2003. "Determinants of Innovation in Small Food Firms". European Journal of Innovation Management, 6 , 817.

Barney, J. 1991. "Firm Resources and Sustained Competitive Advantage". Journal of Management, 17(1), 99-120.

Barney, J. 2007. "Gaining and Sustaining Competitive Advantage (Third Edition)". New Jersey: Pearson Education. 
Barney, J., and Clark, D. 2007. "Resource-Based Theory: Creating and Sustaining Competitive Advantage". New York: Oxford University Press.

Benner, M., and Tushman, M. 2003. "Exploitation, Exploration, and Process Management: The Productivity Dilemma Revisited". Acedemy of Management Review, 28(2), 238-256.

Birkinshaw, J., Hamel, G., and Mol, M. 2008. "Management Innovation". Academy of Management Review, 33(4), 825-845.

Brownell, J. 2008. "Leading on Land and Sea: Competencies and Context". International Journal of Hospitality Management, 27(2), 137-150.

Caloghirou, Y., Kastelli, I., and Tsakanikas, A. 2004. "Internal Capabilities and External Knowledge Sources: Complements or Substitutes for Innovative Performance? "Technovation, 24, 29-39.

Camelo-Ordaz, C., Pérez-Luño, A., and SousaGinel, E. 2009. "The Impact of Market and Entrepreneurial Orientation on Innovativeness: An Empirical Assessment". International Journal of Entrepreneurship and Innovation Management, 10(3/4), 243265.

Carneiro, A. 2000. "How does Knowledge Management Influence Innovation and Competitiveness? " Journal of Knowledge Management, 4(2), 87-98.

Chiang, Y., and Hung, K. 2010. "Exploring Open Search Strategies and Perceived Innovation Performance from The Perspective of Inter-organizational Knowledge Flows". R\&D Management, 40(3), 292-299.

Cooper, D., and Schindler, P. 2014. "Business Research Methodes (12th Edition) ". New York: McGraw Hill Education.

Deichmann, D., and Stam, D. 2015. "Leveraging Transformational and Transactional Leadership to Cultivate The Generation of Organization-Focused Ideas". The Leadership Quarterly, 26, 204-219.

Deichmann, D., and Van den Ende, J. 2014. "Rising From Failure and Learning From Success: The Role of Past Experience in Radical Initiative Taking". Organization Science, 25(3), 670-690.
Drees, J. M., and Heugens, P. 2013. "Synthesizing and Extending Resource Dependence Theory: A Meta-Analysis". Journal of Management, 39(6), 1666-1698.

Elche-Hotelano, D. 2011. "Sources of Knowledge, Investments and Appropriability as Determinants of Innovation: An Empirical Study in Service Firms". Innovation: Management, Policy \& Practice, 13, 220235.

Ferreras-Méndez, J. L., Newell, S., FernándezMesa, A., and Alegre, J. 2015. "Depth and Breadth of External Knowledge Search and Performance: The Mediating Role of Absorptive Capacity". Industrial Marketing Management, 47, 86-97.

Frenz, M., and Letto-Gillies, G. 2009. "The Impact on Innovation Performance of Different Sources of Knowledge: Evidence from The UK Community Innovation Survey". Research Policy, 38, 1125-1135.

Ganotakis, P., and Love, J. H. 2012. "The Innovation Value Chain in New Technology-Based Firms: Evidence from the U.K.".Journal Production and Innovation Management, 5(29), 839-860.

Gaynor, G. 2002. "Innovation by Design: What It Takes to Keep Your Company on The Cutting Edge". New York: AMACOM American Management Association.

Grant, R. 1996. "Toward A Knowledge-Based Theory of The Firm". Strategic Management Journal, 17, 109-122.

Hadjimanolis, A. 2000. "An Investigation of Innovation Antecedents in Small Firms in The Context of A Small Developing Country". R\&D Management, 30(3), 235245.

Hair, J., Black, W., Babin, B., and Anderson, R. 2009. "Multivariate Data Analysis (Seventh Edition)". New Jersey: Pearson.

Hansen, M., and Birkinshaw, J. 2007. "The Innovation Value Chain". Harvard Business Review.

Harrington, R. 2004. "Part I: The Culinary Innovation Process-A Barrier to Imitation". Journal of Foodservice Business Research, 7(3), 35-56.

Harrington, R., and Ottenbacher, M. 2013. "Managing The Culinary Innovation 
Process: The Case of New Product Development". Journal of Culinary Science \& Technology, 11, 4-18.

Henttonen, K., and Ritala, P. 2013. "Search Far and Deep: Focus of Open Search Strategy as Driver of Firm's Innovation Performance". International Journal of Innovation Management, 17(3), 1340007-1 s.d. 1340007-20.

Henttonen, K., Ritala, P., and Jauhiainen, T. 2011. "Exploring Open Search Strategies and Their Perceived Impact on Innovation Performance-Empirical Evidence". International Journal of Innovation Management, 15(3), 525-541.

Hillman, A., Withers, M., and Collins, B. 2009. "Resource Dependence Theory: A Review". Journal of Management, 35(6), 1404-1427.

Huang, F., and Rice, J. 2012. "Openness in Product and Process Innovation". International Journal of Innovation Management, 16(4), 1250020-1 s.d. 1250020-24.

Indarti, N. 2010. "The Effect of Knowledge Stickiness and Interaction on Absorptive Capacity: Evidence from furniture and software Small and Medium Enterprises in Indonesia". Groningen: University of Groningen.

Indarti, N., and Langenberg, M. 2004. "Factors affecting business success among SMEs: Empirical evidences from Indonesia". Proceedings of The Second Bi-annual European Summer University 2004. Enschede, The Netherlands: University of Twente.

Johannessen, J., Olsen, B., and Lumpkin, G. 2001. "Innovation as newness: What is new, how new, and new to whom?"European Journal of Innovation Management, 4(1), 20-31.

Kale, D. 2012. "Innovative Capability Development in The Indian Pharmaceutical Industry". International Journal of Innovation and Technology Management, 9(2), 1250013-1 s.d. 1250013-19.

Katila, R., and Ahuja, G. 2002. "Something Old, Something New: A Longitudinal Study of Search Behavior and New Product Introduction". Academy of Management Journal, 45(6), 1183-1194.

Katz, R., and Allen, T. 1982. "An Emiprical Test of The Not Invented Here (NIH) Syndrome:
A Look at The Performance Tenure, and Communication Pattern of $R \& D$ Project Groups". R\&D Management, 12(1), 7-20.

Koc, T., and Ceylan, C. 2007. "Factor Impacting The Innovative Capacity in Large-Scale Companies". Technovation, 27, 105-114.

Laursen, K., and Salter, A. 2006. "Open for Innovation: The Role of Openness in Explaining Innovation Performance Among U.K. Manufacturing Firms". Strategic Management Journal, 27, 131-150.

Lawson, B., and Samson, D. 2001. "Developing Innovation Capability in Organisations: A Dynamic Capabilities Approach". International Journal of Innovation Management, 5(3), 377-400.

Liao, S., Fei, W., and Chen, C. 2007. "Knowledge Sharing, Absorptive Capacity, and Innovation Capability: An Empirical Study of Taiwan's Knowledge-Intensive Industries". Journal of Information Science, 33(3), 340-359.

Liu, M., and Liu, N. 2008. "Sources of Knowledge Acquisition and Patterns of Knowledge-Sharing Behaviors-An Empirical Study of Taiwanese High-Tech Firms". International Journal of Information Management, 28, 423-432.

March, J. 1991. "Exploration and Exploitation in Organizational Learning". Organization Science, 2(1), 71-87.

Metters, R., King-Metters, K., and Pullman, M. 2003. "Successful Service Operations Management". Canada: Thomson SouthWestern.

Muller, C. C. 1999. "The Business of Restaurants: 2001 and Beyond". International Journal of Hospitality Management, 18(4), 401-413.

Najib, M., and Kiminami, A. 2011. "Innovation, Cooperation and Business Performance (Some Evidence from Indonesian Small Food Processing Cluster)". Journal of Agribusiness in Developing and Emerging Economics, 1(1), 75-96.

Neely, A., Filippini, R., Forza , C., Vinelli, A., and Hii, J. 2001. "A Framework for Analysing Business Performance, Firm Innovation and Related Contextual Factors: Perceptions of Managers and Policy Makers 
in Two European Regions". Integrated Manufacturing Systems, 12(2), 114-124.

Nonaka, I. 1991. "The Knowledge-Creating Company". Harvard Business Review, 96104.

Ottenbacher, M., and Harrington, R. J. 2007. "The Culinary Innovation Process". Journal of Culinary Science \& Technology, 5(4), 935.

Parashar, M., and Singh, S. 2005. "Innovation Capability". IIMB Management Review, 115-123.

Parida, V., Westerberg, M., and Frishammar, J. 2012. "Inbound Open Innovation Activities in High-Tech SMEs: The Impact on Innovation Performance". Journal of Small Business Management, 50(2), 283-309.

Pfeffer, J., and Salancik, G. 2003. "The External Control of Organizations: A Resource Dependence Perspective". California: Standord University Press.

Rogers, E. 2003. "Diffusion of Innovation (Fifth Edition)". New York: Free Press.

Romijn, H., and Albaladejo, M. 2002. "Determinants of Innovation Capability in Small Electronics and Software Firms in Southeast England". Research Policy, 31, 1053-1067.

Roper, S., Du, J., and Love, J. 2008. "Modelling The Innovation Value Chain". Research Policy, 37, 961-977.

Salge, T., Farchi, T., Barrett, M., and Dospon, S. 2013. "When Does Search Openness Really Matter? A Contigency Study of Health-Care Innovation Projects". Journal of Production Innovation Management, 30(4), 659-676.

Schumpeter, J. A. 1934. "The Theory of Economic Development". Cambridge: Harvard University Press.

Sharma, A., and Christie, I. T. 2010. "Performance Assessment Using Value-Chain Analysis in Mozambique". International Journal of Contemporary Hospitality Management, 22(3), 282-299.

Stanworth, M., and Curran, L. 1976. "Growth and The Small Firm: An Alternative View". Journal of Management Studies, 13(2), 97110.

Subramaniam, M., and Youndt, M. 2005. "The Influence of Intellectual Capital on The
Types of Innovative Capabilities". Academy of Management Journal, 48(3), 450-463.

Team of Study and The Ministry of Tourism and Creative Economy. 2014. "Ekonomi Kreatif: Kekuatan Baru Indonesia Menuju 2025 [Creative Economy: Indonesia's New Strength Towards 2025]". Jakarta: PT Republik Solusi.

Team of Study and The Ministry of Tourism and Creative Economy. 2015. "Ekonomi Kreatif: Rencana Pengembangan Kuliner Nasional 2015 - 2019[Creative Economy: The National Culinary Development Plan 2015 - 2019]". Jakarta: PT Republik Solusi.

The Ministry of Tourism and Creative Economy. 2014. "Perkembangan Usaha Restoran/ Rumah Makan Berskala Menengah dan Besar menurut Provinsi 2007 - 2012[The Development of Medium and LargescaleRestaurants by Province 2007 2012]". Retrieved September 17, 2015. Available at: http://www.kemenpar.go.id/ asp/detil.asp?c=114\&id=1430.

Tidd, J., and Bessant, J. 2009. "Managing Innovation: Integrating Technological, Market, and Organizational Change (4rd ed)". The Atrium, Southern Gate, Chichester, England: John Wiley \& Sons Ltd.

Van de Vrande, V., De Jong, P. J., Vanhaverbeke, W., and De Rochemont, M. 2009. "Open Innovation in SMEs: Trends, Motives And Management Challenges". Technovation, 29, 423-437.

Van den Ende, J., Frederiksen, L., and Prencipe, A. 2014. "The Front End of Innovation: Organizing Search for Idea". Journal of Product Innovation Management, 1-6.

Van Djik, C., and Van den Ende, J. 2002. "Suggestion Systems: Transferring Employee Creativity Into Practicable Ideas". $R \& D$ Management, 32(2), 387-395.

Van Geenhuizen, M., and Indarti, N. 2005. "Knowledge As A Critical Resource In Innovation Among Small Furniture Companies in Indonesia". Gadjah Mada International Journal of Business, 7(3), 371-390.

Verworn, B. 2009. "Does Age Have An Impact on Having Ideas? An Analysis of The Quantity and Quality of Ideas Submitted to 
A Suggestion System". Creativity and Innovation Management, 18(4), 326-334.

Vrgovic, P., Vidicki, P., Glassman, B., and Walton, A. 2012. "Open Innovation for SMEs in Developing Countries-An Intermediated Communication Network Model for Collaboration Beyond Obstacles". Innovation: Management, Policy \& Practice, 14(3).

Wang, Y., and Qualls, W. 2007. "Towards a Theoretical Model of Technology Adoption in Hospitality Organizations". International
Journal of Hospitality Management, 26(3), 560-573.

Zander, U., and Kogut, B. 1995. "Knowledge and The Speed of The Transfer and Imitation of Organizational Capabilities: An Empirical Test". Organization Science, 6(1), 76-92.

Ziesemer, T. 2013. "A Knowledge-Based View of The Porter Hypothesis". Environmental Policy and Governance, 23, 193-208.

Notice: The Journal of Indonesian Economy and Business including the Editors decline all errors and flaws found in this article. Authors are fully responsible for them. 